\title{
Mapping water uptake in an epoxy-phenolic coating
}

DOI:

10.1016/j.porgcoat.2015.05.017

https://doi.org/10.1016/j.porgcoat.2015.05.017

\section{Document Version}

Accepted author manuscript

Link to publication record in Manchester Research Explorer

\section{Citation for published version (APA):}

Morsch, S., Lyon, S., Smith, S., \& Gibbon, S. (2015). Mapping water uptake in an epoxy-phenolic coating. Progress in Organic Coatings, 86, 173-180. https://doi.org/10.1016/j.porgcoat.2015.05.017, https://doi.org/10.1016/j.porgcoat.2015.05.017

\section{Published in:}

Progress in Organic Coatings

\section{Citing this paper}

Please note that where the full-text provided on Manchester Research Explorer is the Author Accepted Manuscript or Proof version this may differ from the final Published version. If citing, it is advised that you check and use the publisher's definitive version.

\section{General rights}

Copyright and moral rights for the publications made accessible in the Research Explorer are retained by the authors and/or other copyright owners and it is a condition of accessing publications that users recognise and abide by the legal requirements associated with these rights.

\section{Takedown policy}

If you believe that this document breaches copyright please refer to the University of Manchester's Takedown Procedures [http://man.ac.uk/04Y6Bo] or contact uml.scholarlycommunications@manchester.ac.uk providing relevant details, so we can investigate your claim.

\section{OPEN ACCESS}


MAPPING WATER UPTAKE IN AN EPOXY-PHENOLIC NETWORK

S. Morsch ${ }^{* 1}$, S. Lyon ${ }^{1}$, S. D. Smith, ${ }^{2}$ S. R. Gibbon ${ }^{3}$

${ }^{1}$ Corrosion and Protection Centre,

School of Materials,

The University of Manchester,

The Mill,

Sackville St,

Manchester, M13 9PL, UK

${ }^{2}$ Akzo Nobel Chemicals bv, Supply Chain, Research \& Development, P.O. Box 10,

7400 AA Deventer, NL

${ }^{3}$ Akzo Nobel,

Supply Chain, Research \& Development,

Stoneygate Lane,

Felling,

Gateshead,

Tyne \& Wear, NE10 0JY, UK

To whom correspondence should be addressed.

suzanne.morsch@manchester.ac.uk tel: +44 1613062914 


\begin{abstract}
Water sorption in epoxy networks is associated with deleterious physical effects such as swelling, hydrolysis, lowering of the Tg, cracking and crazing. Nonetheless, water uptake in epoxy coatings is poorly understood in relation to macromolecular structure. In this contribution, we study the effect of cure time (closely related to cross-linking density and free volume) on water uptake for a model epoxy-phenolic coating. Localised water uptake is then mapped with nanoscale lateral resolution using AFM-IR, and correlated to cross-linking density.
\end{abstract}

Keywords: AFM-IR, epoxy-phenolic, water, free volume. 


\section{INTRODUCTION}

Epoxy resins are commonly used as binding agents in the complex formulations comprising marine,[1] aerospace[2][3][4] and coil coatings[5][6]. These resins are known to confer excellent mechanical properties,[7][8] chemical resistance,[9] anti-corrosive properties[10][11][12] and thermal stability[13][14] due to their highly cross-linked nature. However, some degree of water uptake is characteristic of epoxy resins, and has been demonstrated to induce swelling,[15][16] hydrolysis,[17][18] crazing,[19] cracking,[20] plasticization[21] and lowering of the $T_{g}$.[22][23] Localised water uptake by epoxy components may therefore represent failure points in the mechanical integrity of a coating, compromising barrier properties. A comprehensive understanding of the macromolecular structures underpinning water sorption is therefore a key step towards the delivery of coatings with improved long term properties.

In the case of epoxy networks, structure-property relationships have previously been evaluated by correlating bulk resin properties to overall water uptake, which is measured using techniques such as NMR,[24][25] FTIR,[26][27][28][29][30] fluorescence,[31] dielectric spectroscopy[32][33] or gravimetric analysis.[34][35] For example, positron annihilation lifetime spectroscopy (PALS) has recently been instrumental in defining the role of free volume contained within epoxy resins. A number of studies have concluded that resins containing a greater proportion of free volume absorb more water when polarity is controlled.[36][37][38][39][40] Equilibrium water uptake is, however, primarily determined by the hydrogen bonding capability of the network (polarity).[41][42][43][44] In such studies, the polarity and/or 
free volume of resins is commonly controlled using the cross-linker to epoxy ratio[33][45] or else the chemical structure of the cross-linker.[36][46][47] When considering localised water uptake however, a major source of heterogeneity lies in the distribution of cross-linking density, which is typically large for epoxy resins (characterised by high molecular weight distributions prior to gelation, yielding broad $T_{g}$ transitions by DSC analysis[48][49]). Therefore, defining the relationship between cross-linking density and network polarity/free volume could provide an indication of how water uptake is expected to vary across an epoxy resin. To this end, in the present study we assess water uptake for a series of model thermoset epoxy-phenolic coatings produced using different cure schedules. Furthermore, the obtained correlation between cure degree and water sorption is then demonstrated to exist across such a coating by directly mapping cross-linking density and water uptake using AFM-IR.

Few studies have identified localised water uptake in epoxy resins, due to a dearth of techniques capable of mapping chemical functionality under ambient/humid conditions. Acoustic microscopy has been used to map solutions present in blisters beneath organic coatings after corrosion onset, but the small volume of water absorbed by epoxy resins prior to coating failure (typically $<2$ wt \%) has not been detected.[50][51][52] Alternatively, vibrational microspectroscopy techniques such as Fourier transform IR microscopy are capable of directly mapping chemical functionality, however this approach traditionally suffers an inherent diffraction limited resolution associated with the wavelength of light in the mid-IR spectral range, typically several microns per pixel. Recently, the AFMIR approach has been shown to 
circumvent this limitation, by using photothermally induced resonance (PTIR) of an AFM probe in contact with the surface to detect highly localised IR absorbance.[53][54] During AFM-IR, the sample is illuminated by a tunable infrared laser, which is pulsed rapidly. On absorbance, abrupt thermal expansion of the sample excites an AFM probe in contact with the sample surface to oscillate at its resonance frequency modes (Scheme 1). It has been shown that the amplitude of this oscillation is proportional to IR absorbance, so that plotting the amplitude of induced resonance vs. IR wavelength yields spectra closely matched to those obtained by macroscopic transmissionmode FTIR.[55] Furthermore, the laser pulse (10 ns duration), thermal expansion and damping down of the induced resonance occur on a faster timescale than the feedback electronics of the AFM, enabling simultaneous contact-mode topographical measurement and localised IR absorbance mapping at a given wavelength.[54] AFM-IR imaging in this manner has previously been applied to detect nanoscale structures for a variety of materials including polymer blends,[56][57][58] biological samples[59][60][61][62][63][64] and composites.[65] Moreover, AFM-IR has also been used to identify water transport channels in Nafion networks with dimensions of approximately $20 \mathrm{~nm}$.[66]

In the present study, bulk water uptake is evaluated for a simple model epoxy-phenolic consisting of bisphenol-A diglycidyl ether cross-linked with 1,1,1-tris(4-hydroxyphenyl)ethane (Scheme 2). The obtained correlation between cross-linking (degree of cure) and water uptake is then verified by mapping the local degree of cross-linking and correlating this to water uptake measured under humid conditions using AFM-IR. 


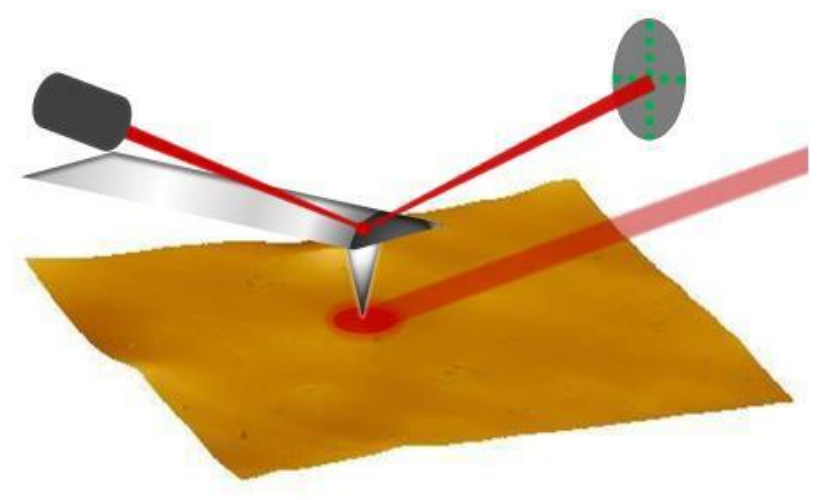

Scheme 1. Experimental set-up of AFM-IR with top-down illumination.

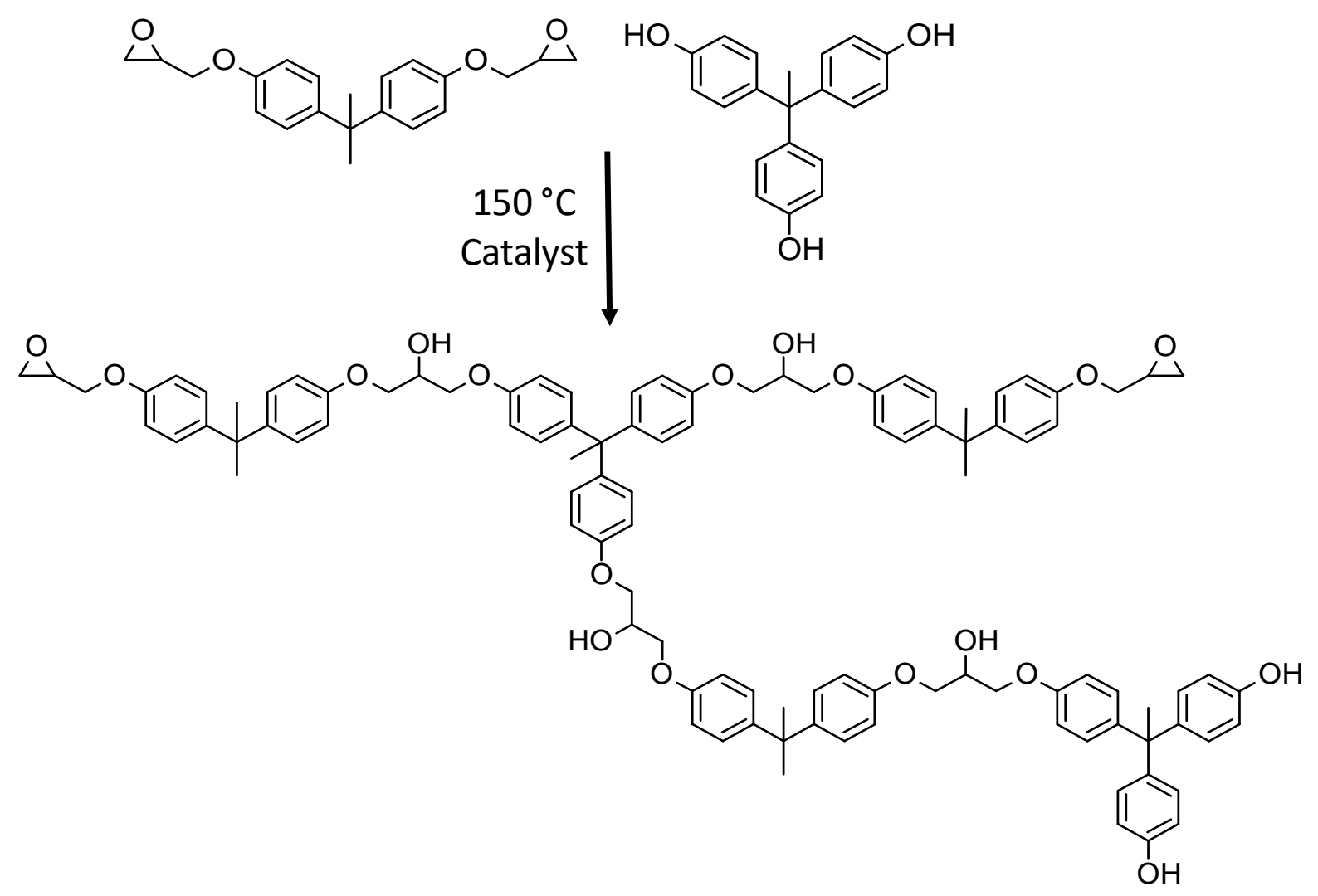

Scheme 2. The cross-linking reaction between bisphenol-A diglycidyl ether and 1,1,1-tris(4-hydroxyphenyl)ethane catalysed by tetrabutylphosphonium bromide. 


\section{EXPERIMENTAL}

\subsection{Sample Preparation}

$3.06 \mathrm{~g}$ (10 mmol) 1,1,1-tris(4-hydroxyphenyl)ethane (99\%, Sigma-Aldrich) and $0.10 \mathrm{~g}(0.3 \mathrm{mmol})$ tetrabutylphosphonium bromide (+98 \%, SigmaAldrich) were dissolved in $6.0 \mathrm{~g}$ acetone (> $98 \%$, Fisher). $5.16 \mathrm{~g}(15 \mathrm{mmol})$ bisphenol-A diglycidyl ether (DER332, epoxide equivalent weight $172-176 \mathrm{~g}$ $\mathrm{mol}^{-1}$, Sigma-Aldrich) was then added and stirred until a homogeneous mixture was obtained. This solution was cast onto electrolytic chrome-coated steel pieces $\left(4 \mathrm{~cm}^{2}\right)$ which had been degreased by sonic cleaning in ethanol (Fisher Scientific, $>99 \%$ ). Spin coating was performed at $2000 \mathrm{rpm}$ for $30 \mathrm{~s}$ (Headway Research Inc., 1-10,000 rpm) then samples were cured by placing in an oven maintained at $150{ }^{\circ} \mathrm{C}$ for a prescribed time interval (5-60 min).

\subsection{Film Characterisation}

Infrared spectra were obtained from 64 co-averages collected in ATR mode using an FTIR spectrometer (Nicolet 5700 spectrometer, Thermo Electron Corp.) operating at $4 \mathrm{~cm}^{-1}$ resolution across the $500-4000 \mathrm{~cm}^{-1}$ range.

For modulated DSC, epoxy-phenolic coatings were mechanically removed from the substrate and 1-3 $\mathrm{mg}$ placed in closed aluminium pans. DSC traces were obtained over a temperature range of $-90{ }^{\circ} \mathrm{C}$ to $300{ }^{\circ} \mathrm{C}$ under nitrogen, using a heating / cooling rate of $3^{\circ} \mathrm{C} \min ^{-1}$ with a modulation period of $\pm 1{ }^{\circ} \mathrm{C} \min ^{-1}$ (Q100 modulated DSC, TA Instruments).

Sessile contact angles were obtained using $5 \mu \mathrm{L}$ droplets of high purity water at $20{ }^{\circ} \mathrm{C}$, and analysed with video capture apparatus (FTA188 Tensiometer, FTA Europe). 
Film thickness was assessed using a scanning electron microscope (Zeiss Evo 50). Spin-coated samples were sputtered with gold (Polaron, E5100) and mounted at $90^{\circ}$ in araldite resin (10:1 Araldite AY 103-1:Aradur HY 951, Huntsman). Once set (after $>48$ h), cross-sections were polished and carbon coated (Edwards E306) prior to analysis.

\subsection{Water Uptake}

Gravimetric water uptake was analysed for free-standing films acquired by cathodic delamination. Coatings were removed from tin-plated steel by application of $+3 \vee$ (vs calomel reference electrode) for $1 \mathrm{~h}$. After removal from the substrate, the films were soaked in deionised water and then dried in a desiccator for 4 days. The thus-obtained free standing films yielded unchanged ATR-FTIR spectra and contact angles on both sides, indicating that polymer films were unaffected by the delamination procedure. For gravimetric uptake, films were accurately weighed, placed in a chamber under $80 \% \mathrm{RH}$ for $2 \mathrm{~h}$ and then re-weighed.

AFM-IR was performed on a NanolR2 system (Anasys Instruments). Images were obtained in contact mode at a scan rate of $0.04 \mathrm{~Hz}$ using a goldcoated silicon nitride probe (Anasys Instruments, $0.07-0.4 \mathrm{~N} / \mathrm{m}$ spring constant, $13 \pm 4 \mathrm{kHz}$ resonance frequency). An optical parametric oscillator nanosecond laser is used as the source of IR radiation incident on the sample, which is subjected to pulses of 10 ns duration at a repetition rate of 1 $\mathrm{KHz}$. The amplitude of resulting photothermally induced cantilever oscillations is then mapped for the chosen wavelength using 32 co-averages per 1024 points over 300 scan lines. The specimen and AFM head were contained within a sample chamber equipped with a portable temperature and humidity 
logger (Lascar Electronics). In order to raise humidity, saturated $\mathrm{NaCl}$ solution was placed in a recrystallizing dish within the sample chamber and allowed to equilibrate for $24 \mathrm{~h}$. 


\section{RESULTS}

\subsection{Coating Characterisation}

Cross-linking of the epoxy coatings was evaluated using modulated DSC analysis, which yielded increasing $T_{g}$ values with respect to cure time, Figure 1. This primarily occurs within the initial $15 \mathrm{~min}$, after which a more gradual increase is observed. Further evidence was obtained using SEM analysis to gauge coating film thickness, which was found to increase with cure time in the same manner as measured $T_{g}$, Figure 2. Taken alongside the consistent mass measured for coatings generated using the spin coating methodology $\left(1.12 \pm 0.04 \mathrm{mg} \mathrm{cm}^{-2}\right)$ this represents a reduction in the polymer density with respect to cure time. Such a fall in density has previously been shown to occur as a consequence of increased cross-linking density for glassy epoxy networks.[67][68][69]

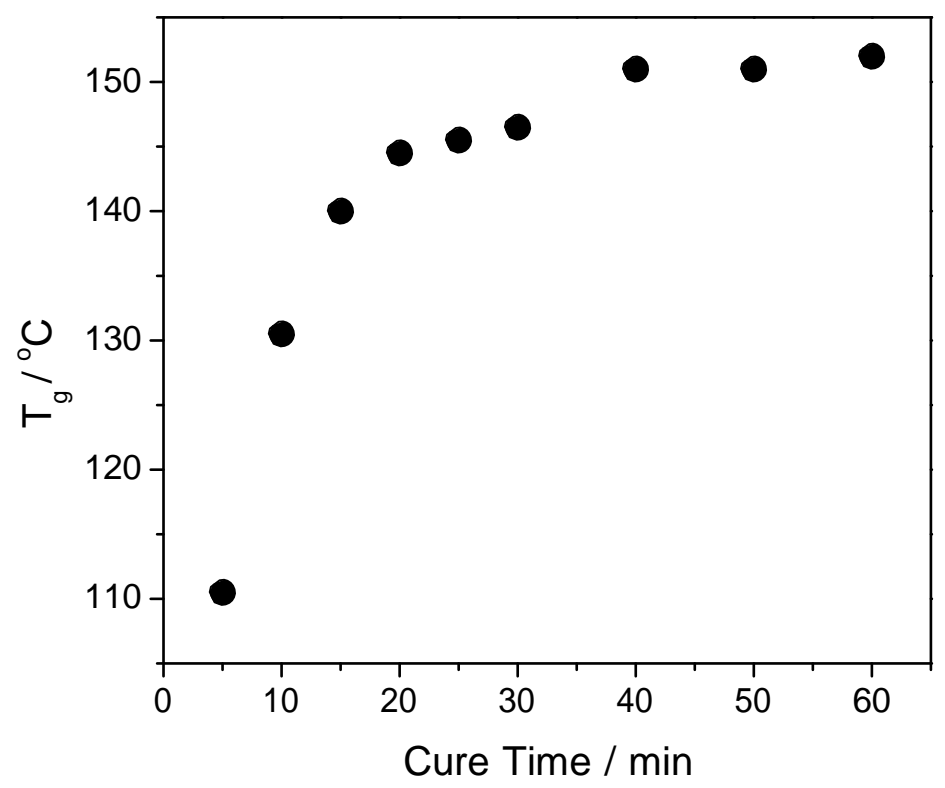

Figure 1. $T_{g}$ of spin coated model epoxy-phenolic films, as a function of cure time at $150{ }^{\circ} \mathrm{C}$. Values were calculated from reversible heat capacity modulated DSC thermograms. 


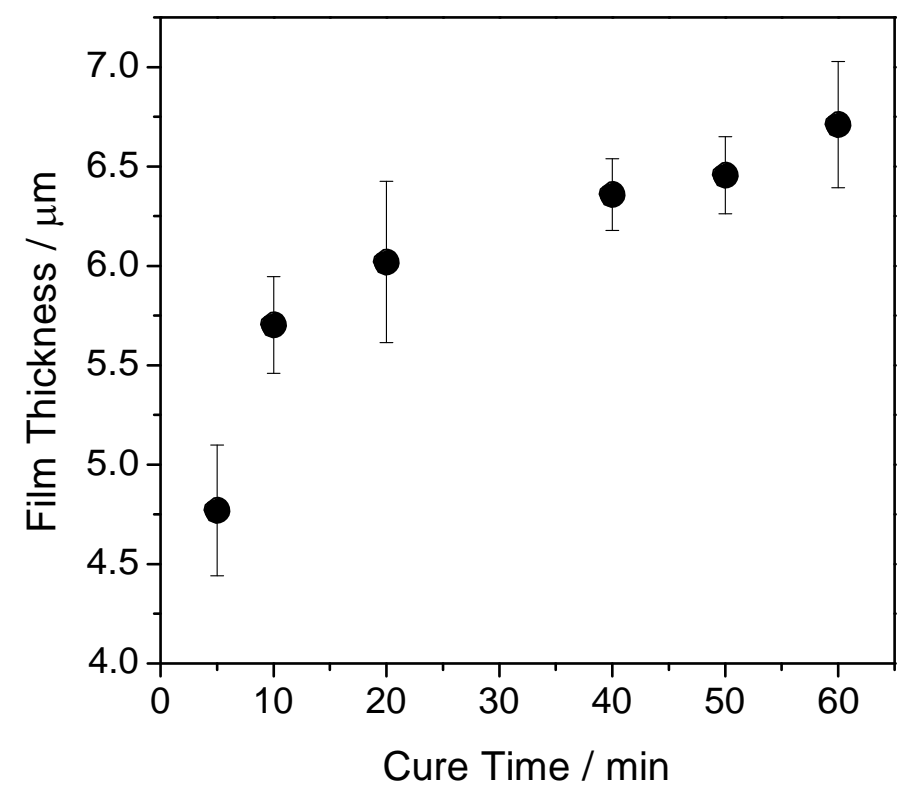

Figure 2. Epoxy-phenolic film thickness (from SEM cross-section analysis) as a function of cure time at $150^{\circ} \mathrm{C}$. Errors correspond to 1 s.d. for 40 individual measurements.

In addition to the measured variation in density, static water contact angles were assessed to give an indication of polarity for the epoxy-phenolic coatings as a function of cure time. Wettability was found to decrease initially on cure (between 5-10 min cure time) then remain constant for more extended curing times, Table 1. This correlates to the cure reaction monitored using macroscopic FTIR, Figure 3. Consumption of the epoxy moiety was verified by the rapid disappearance of the absorbance at $916 \mathrm{~cm}^{-1}$ (asymmetric oxirane ring deformation, clearly observed for bisphenol-A diglycidyl ether) which is visible only for 5 min cured samples, Figure 4. Furthermore, the concurrent appearance of a peak at $1112 \mathrm{~cm}^{-1}$ signifies the generation of secondary hydroxyl groups (secondary alkyl hydroxyl C-O stretch).[70][71] Further characteristic absorbances identified include aryl C-O 
stretches at $1180 \mathrm{~cm}^{-1}$ and $1230 \mathrm{~cm}^{-1}$ and the $\left(\mathrm{CH}_{3}\right)_{2}$ gem dimethyl C-H deformation at $1364 \mathrm{~cm}^{-1}$ and $1381 \mathrm{~cm}^{-1}$.[72][71][73]

Table 1. Static water contact angles for model epoxy-phenolic coatings as a function of cure time at $150^{\circ} \mathrm{C}$.

\begin{tabular}{cc}
\hline Cure Time $/ \mathbf{m i n}$ & Contact Angle $^{\circ}$ \\
\hline 5 & $78 \pm 1$ \\
\hline 10 & $85 \pm 1$ \\
\hline 15 & $82 \pm 2$ \\
\hline 20 & $82 \pm 2$ \\
\hline 25 & $84 \pm 1$ \\
\hline 30 & $83 \pm 1$ \\
\hline 40 & $82 \pm 1$ \\
\hline 50 & $84 \pm 1$ \\
\hline 60 & $82 \pm 1$ \\
\hline
\end{tabular}




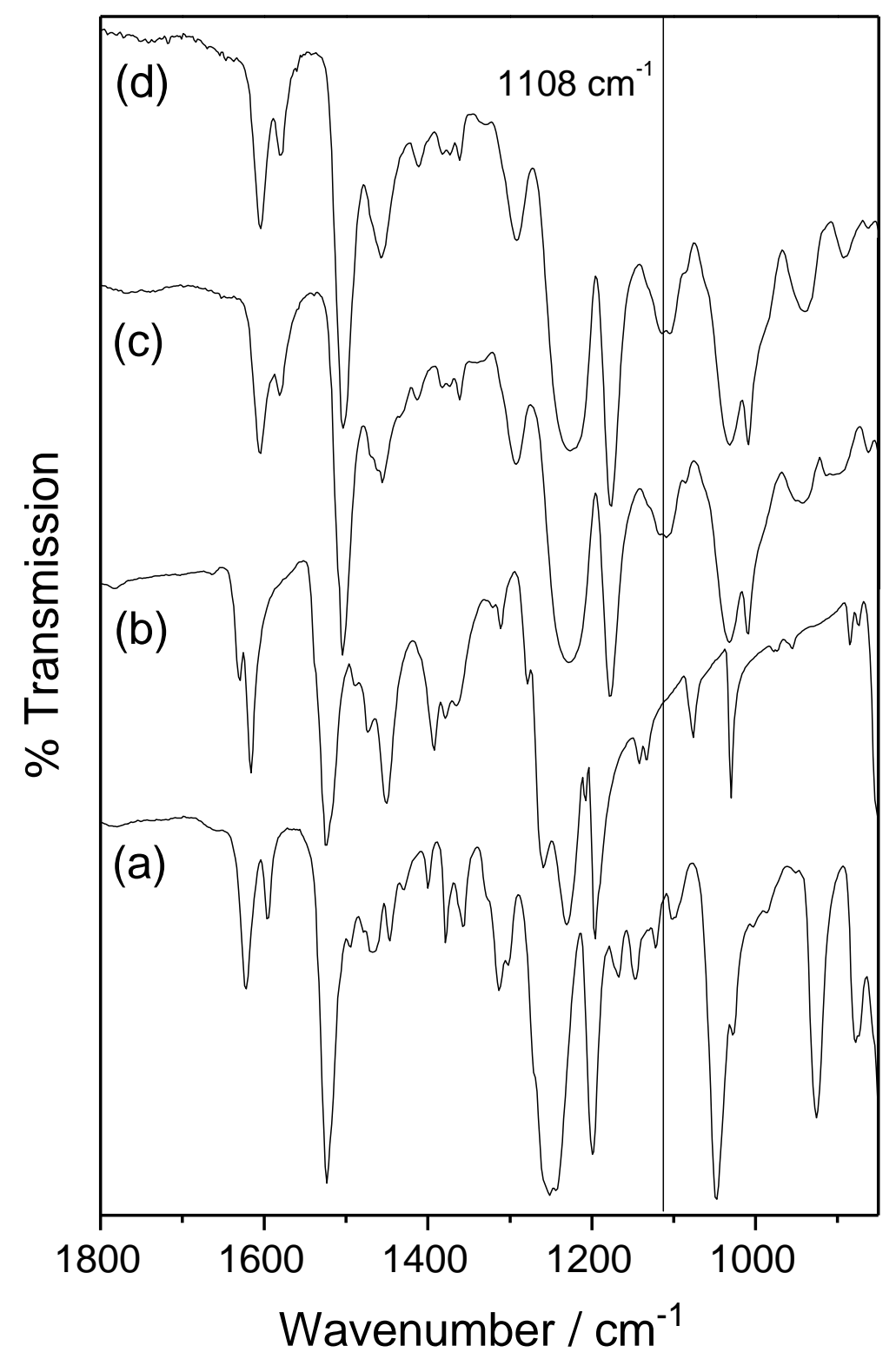

Figure 3. ATR-FTIR spectra for: (a) bisphenol-A diglycidyl ether; (b) 1,1,1tris(4-hydroxyphenyl)ethane cross-linker; (c) model epoxy-phenolic coating cured for 5 min at $150{ }^{\circ} \mathrm{C}$ and (d) model epoxy-phenolic coating cured for 30 $\min$ at $150^{\circ} \mathrm{C}$. 


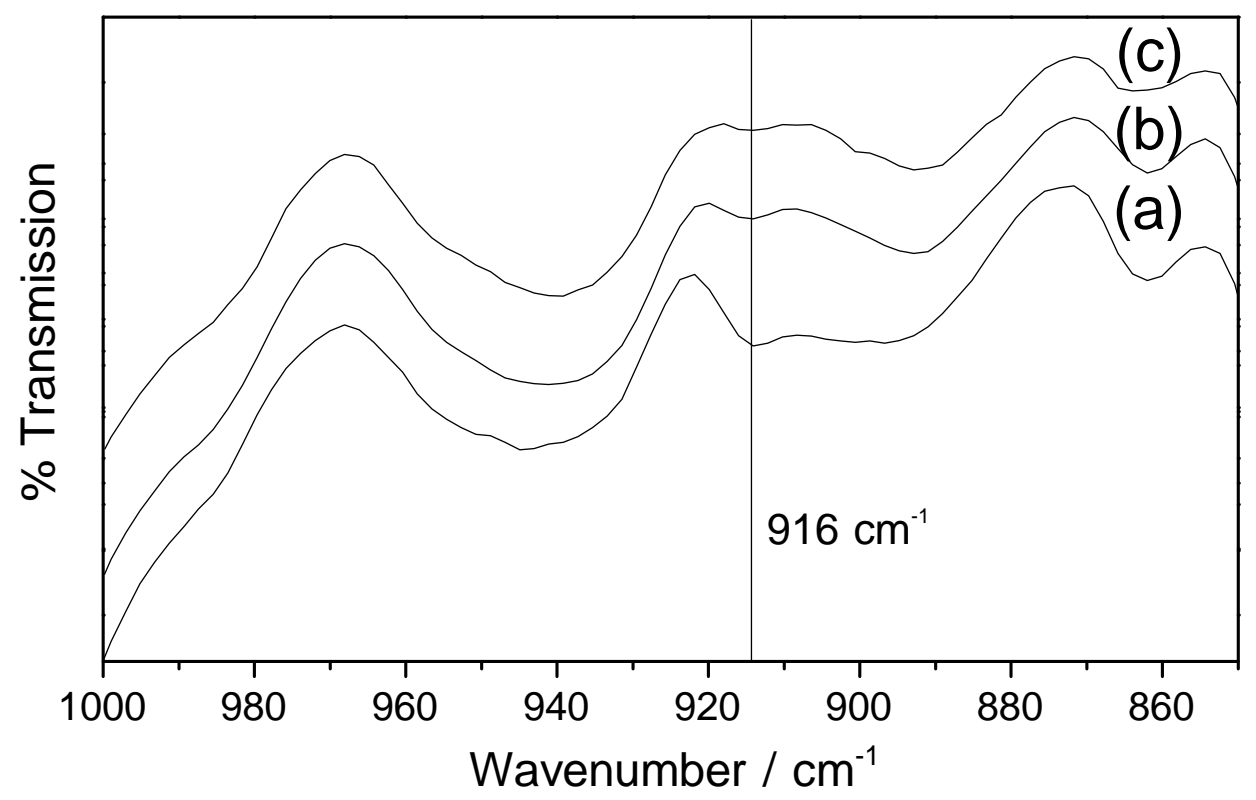

Figure 4. FTIR spectra of spin-coated model epoxy-phenolic coatings cured at $150^{\circ} \mathrm{C}$ for (a) $5 \mathrm{~min}$; (b) $10 \mathrm{~min}$ and (c) $15 \mathrm{~min}$.

Finally, gravimetric water uptake was assessed for free-standing films under humid conditions, and was found to increase for films cured for prolonged times, Figure 5.

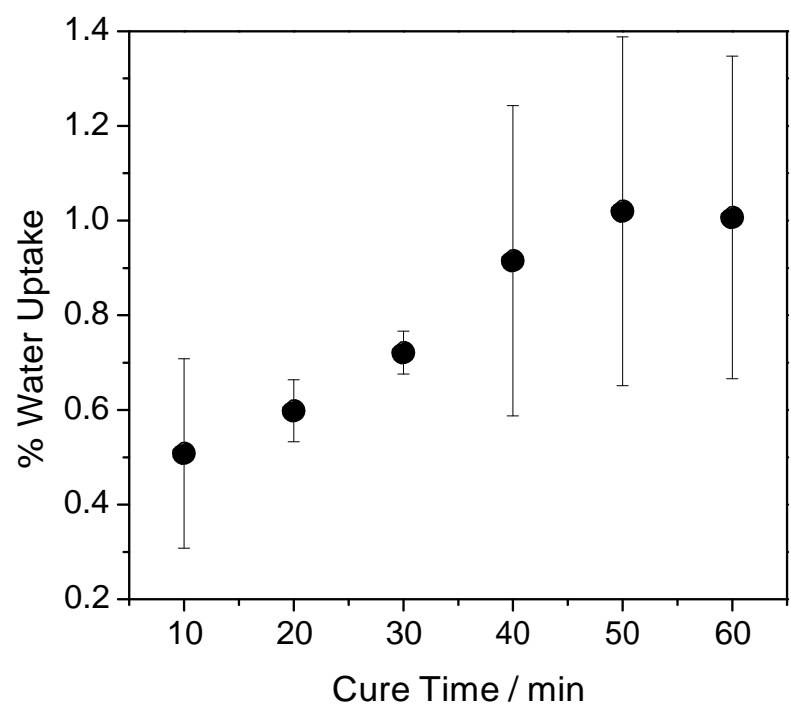

Figure 5. Gravimetrically assessed water uptake (as \% mass) obtained for free standing films of epoxy-phenolic coating as a function of cure time at $150^{\circ} \mathrm{C}$. Error bars correspond to 1 s.d. for 4 individual measurements. 


\subsection{AFM-IR}

In order to investigate local properties, samples cured for 5 min were selected, due to the remnants of the epoxy peak at $916 \mathrm{~cm}^{-1}$ observed in bulk FTIR spectra, which provides a handle for imaging local cure degree, Figure

4. Contact mode AFM measurements revealed a smooth, consistently nodular topography consisting of raised bumps of 2-3 nm height, Figure 6 . Furthermore, AFM-IR mapping at $916 \mathrm{~cm}^{-1}$ shows that these correlate to regions of higher IR amplitude signals (absorbance), indicating of a local concentration of unreacted epoxy groups present in these regions, Figure 6.

In order to correlate the local cure degree to water uptake, the sample was scanned at $3300 \mathrm{~cm}^{-1}$ (corresponding to the $\mathrm{OH}$ stretch absorbance of the epoxy-phenolic resin and water), Figure 6. Under ambient conditions, a slightly higher absorbance is observed over the elevated regions, however under raised humidity this contrast is inverted, indicating that water uptake is concentrated onto the less cross-linked region surrounding the bumps. To further verify this, ratio images were generated from the raw data of IR absorbance maps. Figure 7 shows the ratio images generated from overlapping regions of IR amplitude maps taken at $916 \mathrm{~cm}^{-1}$ and $3300 \mathrm{~cm}^{-1}$ under ambient conditions (Figure 6 (a) and 6 (b)). As $916 \mathrm{~cm}^{-1}$ corresponds to a weak IR peak, this image is noisy, however features identified in the AFM-IR map are still visible and correlate to the height image, demonstrating that the increased signal observed over elevated regions is not due to any difference in sample thickness / topography. Furthermore, the ratio image generated for $3300 \mathrm{~cm}^{-1} \mathrm{IR}$ maps under $35 \% \mathrm{RH}$ and $65 \% \mathrm{RH}$ (Figure 6 (b) and 6 (c)) show the increase in $\mathrm{OH}$ signal on water sorption is localised around the less 
cross-linked, elevated bumps. This local water uptake within less crosslinked regions of the sample is in keeping with the correlation found between water uptake and cure time for bulk samples under humid conditions.
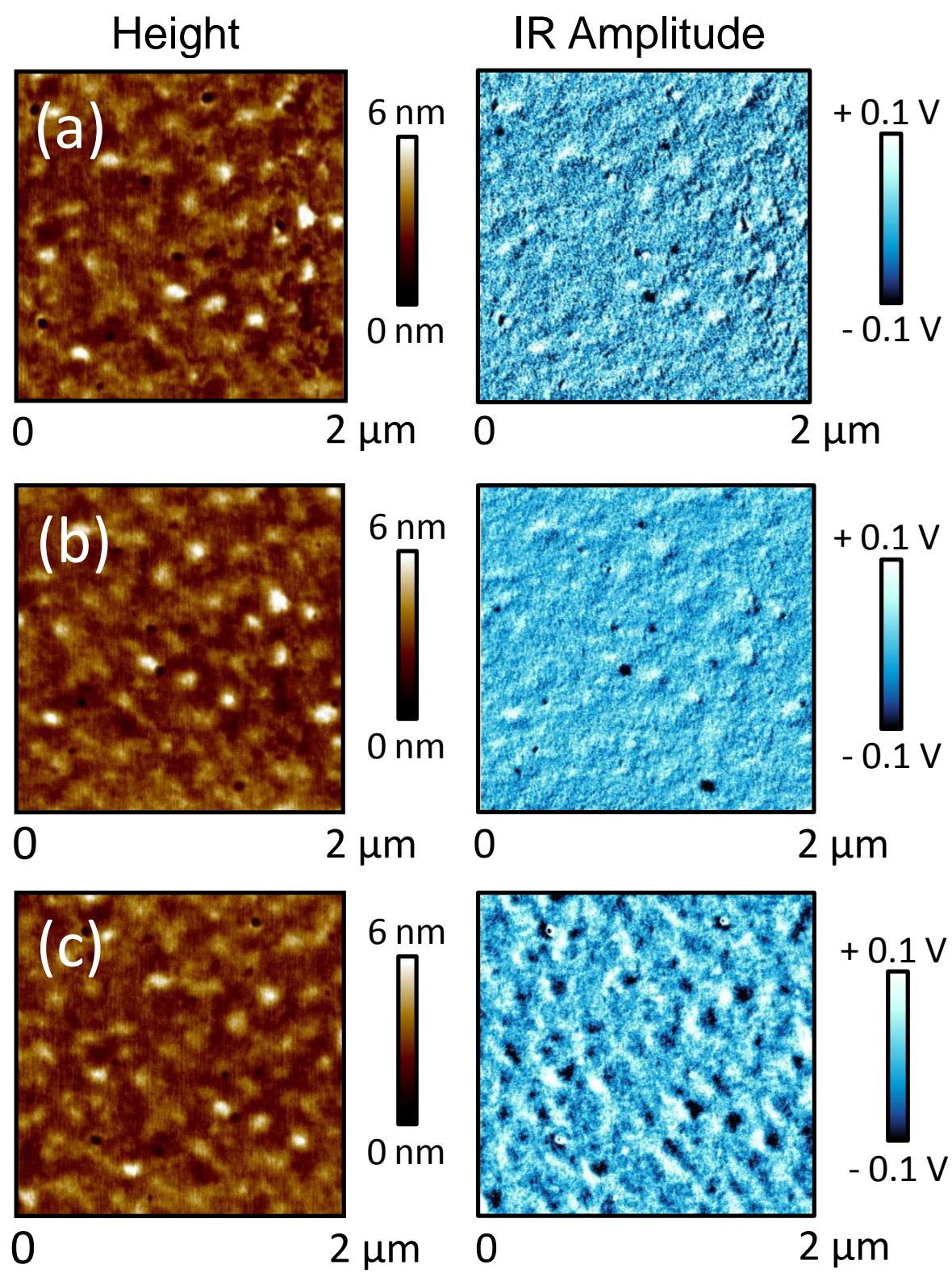

Figure 6. AFM-IR height and corresponding IR amplitude images of 5 min cured epoxy-phenolic coating subjected to pulsed laser illumination at (a) 916 $\mathrm{cm}^{-1}$ under ambient conditions (35\% RH); (b) $3300 \mathrm{~cm}^{-1}$ under ambient conditions (35\% RH) and (c) $3300 \mathrm{~cm}^{-1}$ under raised humidity (65\% $\left.\mathrm{RH}\right)$. The images have been flattened line-by-line for clarity. 

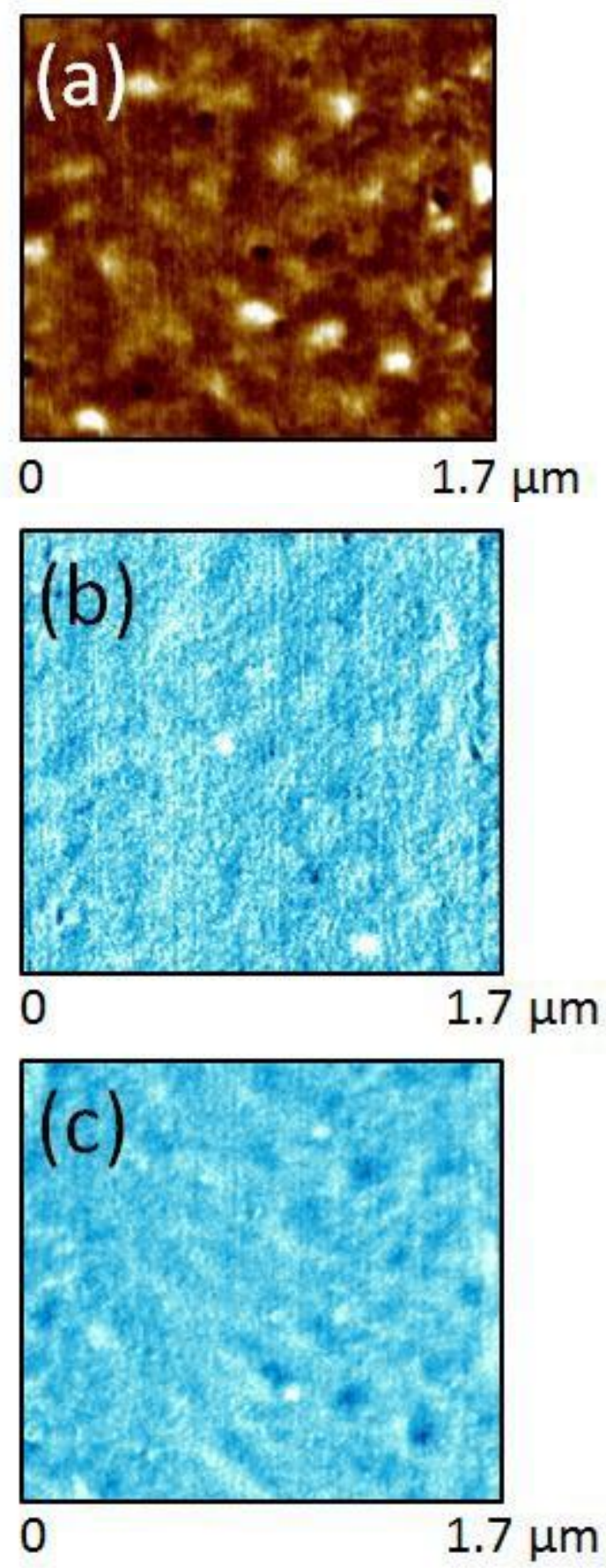

Figure 7. AFM-IR (a) topography and corresponding IR ratio images generated from IR amplitude maps taken using (b) $916 \mathrm{~cm}^{-1} / 3300 \mathrm{~cm}^{-1}$ under $35 \% \mathrm{RH}$ and (b) $3300 \mathrm{~cm}^{-1}$ under $35 \% \mathrm{RH} / 65 \% \mathrm{RH}$. 


\section{DISCUSSION}

Water ingress into epoxy networks can be understood to depend on macromolecular architecture, which varies as a function of cure time due to cross-linking reactions. The increase in equilibrium water uptake observed in the present study stems from the increased proportion of free volume in more highly cross-linked networks (signified by decreasing density of coatings as a function of cure time). For highly cross-linked glassy network polymers such as the epoxy-phenolic coating studied, this increase in free volume is attributed to the network being further from its equilibrium configuration when the structure is frozen on cooling.[69][74] However, a concurrent change in polarity should occur as a consequence of the cross-linking reaction, which inherently involves the transformation of functional groups involved in hydrogen bonding (ether and hydroxyl groups). Static contact angles indicate that coating polarity initially decreases, then stabilises with increased cure time. This initial drop in hydrophilicity coincides with the consumption of epoxide groups and generation of secondary hydroxyl groups detectable by FTIR. In addition, changes in $T_{g}$ and film thickness also primarily occur within this timeframe, indicating that the majority of cross-linking reactions occur within the first 10 minutes of curing. Thus, the cross-linking reaction is actually associated with a drop in resin polarity, which is only detected in early stages when major structural changes occur. According to the current understanding of water sorption into epoxy networks, such a drop in polarity should coincide with decreased moisture uptake. However in the present case, the changes in polarity appear to be minor, such that the accompanying increase in free volume determines overall water uptake instead. 
Since coatings commonly fail in a localised manner, the ability to map polymeric properties such as cross-linking density and water uptake represents a key step towards understanding coating breakdown mechanisms. In the present study, we demonstrate the feasibility of using AFM-IR to map cross-link density and local water uptake for an epoxy coating. The morphology of the generated coating is generally smooth, and variations in cross-linking were found to be highly localised, with nanoscale raised regions corresponding to less cross-linked regions of the network. This finding is surprising in light of previous morphological studies using SEM and AFM, which have identified similar nodular morphologies at the surface of epoxy amine resins.[75][[76][77] Such nodules were previously considered to correspond to floccules of resin surrounded by unreacted material, formed via a diffusion-controlled nucleation mechanism during cure. Localised infrared mapping has enabled chemical probing of these structures for the first time, and shown this is not the case for the epoxy-phenolic network investigated here. Furthermore, utilisation of the AFM-IR technique then allowed direct imaging of water uptake at sub-micron length scales under humid conditions, and water was found to be concentrated within regions of higher crosslinking density, in keeping with the macroscopic results for intact coatings. 


\section{CONCLUSIONS}

Varying the degree of cure in order to control cross-linking density is found to be a promising approach to predict how water uptake varies across a coating. For the epoxy-phenolic coating studied here, bulk equilibrium uptake follows the increase in free volume (cross-linking), in agreement with previous studies detailing water absorption for resins in the absence of polarity effects. Water uptake is then found to be locally enhanced within regions of higher crosslinking density by AFM-IR, in keeping with this relationship.

\section{ACKNOWLEDGMENTS}

S. Morsch would like to thank AkzoNobel for financial support, and Polly Greensmith for her kind assistance with DSC analysis. 


\section{REFERENCES}

[1] B. Chen, M. Guizar-Sicairos, G. Xiong, L. Shemilt, A. Diaz, J. Nutter, et al., T Sci. Rep. 3 (2013) 1177.

[2] A. Toldy, B. Szolnoki, G. Marosi, Polym. Degrad. Stab. 96 (2011) 371376.

[3] G. Williams, R. Trask, I. Bond, Compos. Part A: Appl. Sci. Manuf. 38 (2007) 1525-1532.

[4] J. Njuguna, K. Pielichowski, Adv. Eng. Mater. 5 (2003) 769-778.

[5] J.F. Watts, M.-L. Abel, C. Perruchot, C. Lowe, J.T. Maxted, R.G. White, J. Electron Spectros. Relat. Phenomena. 121 (2001) 233-247.

[6] C. Perruchot, J.F. Watts, C. Lowe, R.G. White, P.J. Cumpson, Surf. Interface Anal. 33 (2002) 869-878.

[7] P. Mani, A. K. Gupta, S. Krishnamoorthy, Int. J. Adhes. Adhes. 7 (1987) 157-163.

[8] J.K. Lancaster, Wear. 14 (1969) 223-239.

[9] A. Wegmann, Prog. Org. Coatings. 32 (1997) 231-239.

[10] S.-Y. Zhang, Y.-F. Ding, S.-J. Li, X.-W. Luo, W.-F. Zhou, Corros. Sci. 44 (2002) 861-869.

[11] S. Zhang, S. Li, X. Luo, W. Zhou, Corros. Sci. 42 (2000) 2037-2041.

[12] M.C.S.S. Macedo, I.C.P. Margarit-Mattos, F.L. Fragata, J.-B. Jorcin, N. Pébère, O.R. Mattos, Corros. Sci. 51 (2009) 1322-1327.

[13] X. Zhang, Q. He, H. Gu, H. a Colorado, S. Wei, Z. Guo, ACS Appl. Mater. Interfaces. 5 (2013) 898-910.

[14] L. Lee, J. Polym. Sci. Part A Gen. Pap. 3 (1965) 859-882.

[15] G.Z. Xiao, M.E.R. Shanahan, Polymer (Guildf). 39 (1998) 3253-3260.

[16] A.F. Abdelkader, J.R. White, J. Mater. Sci. 40 (2005) 1843-1854.

[17] G. Xiao, M. Shanahan, J. Polym. Sci. Part B Polym. Phys. 35 (1997) 2659-2670.

[18] M.K. Antoon, J.L. Koenig, J. Polym. Sci. Polym. Phys. Ed. 19 (1981) 197-212. 
[19] A. Apicella, R. Tessieri, C. de Cataldis, J. Memb. Sci. 18 (1984) 211225.

[20] R. Fedors, Polymer (Guildf). 21 (1980) 713-715.

[21] A. Chateauminois, B. Chabert, J. Soulier, L. Vincent, Polym. Compos. 16 (1995) 288-296.

[22] P. Moy, F.E. Karasz, Polym. Eng. Sci. 20 (1980) 315-319.

[23] J. Li, C.S. Jeffcoate, G.P. Bierwagen, D.J. Mills, D.E. Tallman, Thermal Corrosion. 54 (1998) 763-771.

[24] S. Luo, J. Leisen, C.P. Wong, J. Appl. Polym. Sci. 85 (2002) 1-8.

[25] J. Zhou, J.P. Lucas, Polymer (Guildf). 40 (1999) 5505-5512.

[26] Y. Ngono, Y. Maréchal, J. Polym. Sci. Part B Polym. Phys. 39 (2001) 1129-1136.

[27] P. Musto, G. Ragosta, G. Scarinzi, L. Mascia, J. Polym. Sci. Part B Polym. Phys. 40 (2002) 922-938.

[28] P. Musto, L. Mascia, G. Ragosta, G. Scarinzi, P. Villano, Polymer (Guildf). 41 (2000) 565-574.

[29] J. Mijovic, H. Zhang, J. Phys. Chem. B. 108 (2004) 2557-2563.

[30] S. Cotugno, G. Mensitieri, P. Musto, L. Sanguigno, Molecular Macromolecules. 38 (2005) 801-811.

[31] J. Gonzalez-Benito, J. Bravo, F. Mikes, J. Baselga, Polymer (Guildf). 44 (2003) 653-659.

[32] I.D. Maxwell, R.A. Pethrick, J. Appl. Polym. Sci. 28 (1983) 2363-2379.

[33] C. Grave, I. McEwan, R. Pethrick, J. Appl. Polym. Sci. 69 (1998) 23692376.

[34] M. Liu, P. Wu, Y. Ding, S. Li, Phys. Chem. Chem. Phys. 5 (2003) 18481852.

[35] D. Hayward, E. Hollins, P. Johncock, Polymer (Guildf). 38 (1997) 11511168.

[36] M. Jackson, M. Kaushik, S. Nazarenko, S. Ward, R. Maskell, J. Wiggins, 52 (2011) 4528-4535.

[37] C.L. Soles, F.T. Chang, B.A. Bolan, H.A. Hristov, D.W. Gidley, A.F. Yee, J. Polym. Sci. Part B Polym. Phys. 36 (1998) 3035-3048. 
[38] C.L. Soles, F.T. Chang, D.W. Gidley, A.F. Yee, J. Polym. Sci. Part B Polym. Phys. 38 (2000) 776-791.

[39] C. Soles, A. Yee, J. Polym. Sci. Part B Polym. Phys. 38 (2000) 792802.

[40] M.T. Aronhime, X. Peng, J.K. Gillham, R.D. Small, J. Appl. Polym. Sci. 32 (1986) 3589-3626.

[41] J. Wang, J. Gong, Z. Gong, X. Yan, B. Wang, Q. Wu, et al., Nucl. Instruments Methods Phys. Res. Sect. B: Beam Interact. with Mater. Atoms. 268 (2010) 2355-2361.

[42] L. Li, M. Liu, S. Li, Polymer (Guildf). 45 (2004) 2837-2842.

[43] L. Li, S. Zhang, Y. Chen, M. Liu, Y. Ding, X. Luo, et al., Water Chem. Mater. 17 (2005) 839-845.

[44] L. Li, Y. Yu, Q. Wu, G. Zhan, S. Li, Corros. Sci. 51 (2009) 3000-3006.

[45] V. Gupta, L. Drzal, M. Rich, J. Appl. Polym. Sci. 30 (1985) 4467-4493.

[46] Y. Ding, M. Liu, S. Li, S. Zhang, W.-F. Zhou, B. Wang, Macromol. Chem. Phys. 202 (2001) 2681-2685.

[47] S. Goyanes, W. Salgueiro, A. Somoza, J.A. Ramos, I. Mondragon, Polymer (Guildf). 45 (2004) 6691-6697.

[48] C. Wu, J. Zuo, B. Chu, Macromolecules. 22 (1989) 633-639.

[49] V. Varshney, S.S. Patnaik, A.K. Roy, B.L. Farmer, A. Macromolecules. 41 (2008) 6837-6842.

[50] M. Doherty, J.M. Sykes, Corros. Sci. 46 (2004) 1265-1289.

[51] I. Alig, M. Bargmann, H. Oehler, D. Lellinger, M. Wanner, D. Koch, J. Phys. D. Appl. Phys. 44 (2011) 034009.

[52] H. Oehler, I. Alig, D. Lellinger, M. Bargmann, Prog. Org. Coatings. 74 (2012) 719-725.

[53] A. Dazzi, R. Prazeres, F. Glotin, J.M. Ortega, Infrared Phys. Technol. 49 (2006) 113-121.

[54] A. Dazzi, F. Glotin, R. Carminati, J. Appl. Phys. 107 (2010) 124519-1124519-7.

[55] B. Lahiri, G. Holland, A. Centrone, Small. 9 (2013) 439-45. 
[56] H. Cho, J.R. Felts, M.-F. Yu, L.A. Bergman, A.F. Vakakis, W.P. King, I Nanotechnology. 24 (2013) 444007.

[57] B.V.A.N. Eerdenbrugh, M. Lo, K. Kjoller, C. Marcott, L.S. Taylor, 101 (2012) 2066-2073.

[58] A. Dazzi, C. Prater, Q. Hu, Appl. Spectrosc. OA. 66 (2012) 1365-1384.

[59] C. Mayet, A. Dazzi, R. Prazeres, F. Allot, F. Glotin, J.M. Ortega, Opt. Lett. 33 (2008) 1611-3.

[60] C. Mayet, A. Dazzi, R. Prazeres, J.-M. Ortega, D. Jaillard, Analyst. 135 (2010) 2540-5.

[61] E. Janik, J. Bednarska, M. Zubik, M. Puzio, R. Luchowski, W. Grudzinski, et al., Plant Cell. 25 (2013) 2155-70.

[62] T. Müller, F.S. Ruggeri, A.J. Kulik, U. Shimanovich, T.O. Mason, T.P.J. Knowles, et al., Lab Chip. 14 (2014) 1315-9.

[63] A. Deniset-besseau, C.B. Prater, A. Dazzi, (2014).

[64] C. Marcott, M. Lo, K. Kjoller, F. Fiat, N. Baghdadli, G. Balooch, et al., Appl. Spectrosc. 68 (2014) 564-569.

[65] C. Marcott, M. Lo, Q. Hu, E. Dillon, K. Kjoller, C.B. Prater, (2014) 2-4.

[66] T. Awatani, H. Midorikawa, N. Kojima, J. Ye, C. Marcott, Electrochem. Commun. 30 (2013) 5-8.

[67] V. Gupta, C. Brahatheeswaran, Polymer (Guildf). 32i (1991) 18751884.

[68] K. Pang, J. Gillham, J. Appl. Polym. Sci. 37 (1989) 1969-1991.

[69] V.B. Gupta, L.T. Drzal, C.Y.-C. Lee, M.J. Rich, T., J. Macromol. Sci. Part B - Phys. 23 (1984) 435-466.

[70] C.J. DeBakker, G.A. George, N.A. St John, P.M. Fredericks, Spectochimica Acta. 49 (1993) 739-752.

[71] D. Lin-Vien, N.B. Colthup, W.G. Fateley, J.G. Grasselli, The Handbook of Infrared and Raman Characteristic Frequencies of Organic Molecules, Academic Press Ltd, London, 1991.

[72] K.E. Chike, M.L. Myrick, R.E. Lyon, S.M. Angel, Appl. Spectrosc. 47 (1993) 1631-1635.

[73] L.B. Manfredi, M.J.L. Gines, G.J. Benitez, W.A. Egli, H. Rissone, A. Vazquez, J. Appl. Polym. Sci. 95 (2005) 1448-1458. 
[74] J. Enns, J. Gillham, J. Appl. Polym. Sci. 28 (1983) 2831-2846.

[75] M.R. Vanlandingham, R.F. Eduljee, J.W. Gillespie, J. Appl. Polym. Sci. 71 (1998) 699-712.

[76] R.J. Morgan, E.O. James, Polym. Plast. Technol. Eng. 10 (1978) 49116.

[77] R.E. Cuthrell, J. Appl. Polym. Sci. 12 (1968) 1263-1278. 